\section{Multimodality management of} cavernous sinus meningiomas

with less extensive surgery followed by subsequent

\section{irradiation: Implications for an improved toxicity profile}

\section{Omer Sager*, Murat Beyzadeoglu, Ferrat Dincoglan, Selcuk \\ Demiral, Hakan Gamsiz, Bora Uysal, Onurhan Colak, Fatih \\ Ozcan and Bahar Dirican}

Department of Radiation Oncology; University of Health Sciences, Gulhane Medical Faculty, Ankara, Turkey
Received: 30 May, 2020

Accepted: 06 June, 2020

Published: 08 June, 2020

*Corresponding author: Dr. Omer Sager, Department of Radiation Oncology; University of Health Sciences, Gulhane Medical Faculty, Gn.Tevfik Saglam Cad. 06018 Etlik, Kecioren, Ankara, Turkey, Tel: +90 312304 4683; Fax: +90 312304 4680; E-mail: omersager@gmail.com

Keywords: Meningioma; Cavernous sinus; Radiation therapy (RT); Irradiation; Surgery

ORCID: https://orcid.org/0000-0001-7866-2598

https://www. peertechz.com

(D) Check for updates

\begin{abstract}
Meningiomas comprise the most frequent intracranial benign tumors accounting for approximately one third of all intracranial neoplasms, and generally follow an indolent disease course with a typically benign nature and slow-growing behaviour. Although majority of meningiomas may follow an indolent disease course, affected patients may suffer from a plethora of symptoms with regard to lesion location. Symptoms typically occur as a result of the mass effect leading to compression of critical neurovascular structures. Headache, focal seizures, weakness in the limbs, visual disturbances, loss of smell, impaired memory or hearing functions may be observed. Advances in neurosurgery may allow for an improved toxicity profile following surgical resection as the traditional and a leading mode of management for meningiomas located at accessible brain areas. Nevertheless, vigilance is required given the morbidity and mortality risks associated with meningioma surgery particularly for elderly patients. In this context, radiation therapy (RT) may offer a viable alternative or adjunctive modality of management for meningiomas. Management of cavernous sinus meningiomas in intricate association with critical neurovascular structures pose a formidable challenge to the treating physicians. Attempting at extensive surgical procedures may be associated with substantial morbidity and even mortality. In this context, selected patients may benefit from a tailored multimodality approach including less extensive surgical resection followed by subsequent irradiation. Primary advantages of this refined therapeutic strategy may include improved toxicity profile along with improved functionality and quality of life. Herein, we assess multimodality management of cavernous sinus meningiomas with less extensive surgery followed by subsequent irradiation.
\end{abstract}

\section{Introduction}

Meningiomas comprise the most frequent intracranial benign tumors accounting for approximately one third of all intracranial neoplasms, and generally follow an indolent disease course with a typically benign nature and slow-growing behaviour [1-5]. Incidence of meningiomas demonstrates an age dependency with the highest incidence in the elderly age group $[4,5]$. These dural based tumors are considered to arise from the arachnoid meningothelial cells due to unknown etiology, although exposure to ionizing radiation and background of neurofibromatosis type 2 have been suggested to be in association with meningiomas [3].

Three World Health Organization (WHO) grades with 15 histological subtypes have been included in the WHO classification scheme which underscores the heterogeneity in clinical and molecular characteristics of meningiomas $[1,3,6]$. 
The most prevalent type includes grade 1 meningiomas as per the WHO classification [6]. Nevertheless, meningiomas of higher WHO grades are typically associated with higher recurrence rates and lower survival durations [3]. Also, a preponderance for frequent relapses, malignant transformation an deven metastases may be of concern although not typical [3].

Diverse localization throughout the central nervous system (CNS) may be seen, nevertheless, the most frequent location for meningiomas includes the supratentorial region, followed by skull base and the posterior fossa [7]. Parasagittal meningiomas, parafalcine meningiomas, convexity meningiomas and intraventricular meningiomas are located at the supratentorial brain whereas sphenoid ridge meningiomas, tuberculum sellae meningiomas, olfactory groove meningiomas, petroclival meningiomas, cavernous sinus meningiomas, and intraorbital meningiomas are located at the skull base region, and jugular foramen meningiomas, peritorcular meningiomas. cerebellopontine angle meningiomas, and cerebellar convexity meningiomas are included in the group of posterior fossa meningiomas [7].

Principal imaging modality for meningiomas is magnetic resonance imaging (MRI). However, computed tomography (CT) imaging may have a role in detection of tumoral calcifications, bony changes such as hyperostosis or osteolysis, and intraosseous tumor growth and pneumosinus dilatans especially for skull base lesions [8,9]. Diagnostic features suggestive of meningioma may be present on CT imaging in a considerable proportion of the patients as a lobular and circumscribed lesion with dural attachment $[8,9]$. Visualization is typically homogeneous on unhanced CT as a hyperdense extraaxial lesion with homogeneous contrast enhancement after administration of the contrast media [8,9]. MRI may be used in detection of the dural tail in some patients visualized as a post-contrast linear thickening of the duramater close to the lesion. Meningiomas are typically visualized as hypointense or isointense lesions on T1-weighted MRI and as hyperintense lesions on T2-weighted MRI usually with well defined borders $[8,9]$. While areas of calcification or necrosis may not demonstrate enhancement, homogeneous contrast enhancement is typical on MRI, and MRI may provide improved contrast differentiation to be utilized for differentiation of intraaxial and extraaxial meningioma lesions. Presence of dural tail may be suggestive of reactive dural changes whereas dural tails may also be infiltrated by the tumor in some cases. While not specific to meningiomas only, presence of the dural tail may facilitate differentiation of some meningioma lesions from other tumors not exhibiting dural tail such as pituitary adenomas or schwannomas $[8,9]$.

Incidental detection may account for a considerable proportion of newly diagnosed meningiomas thanks to increased availability and use of modernized diagnostic imaging modalities [10-12]. Nevertheless, affected meningioma patients may also present with a plethora of symptoms with regard to lesion location. Symptoms typically occur as a result of the mass effect leading to compression of critical neurovascular structures. Headache, focal seizures, weakness in the limbs, visual disturbances, loss of smell, impaired memory or hearing functions may be observed.

Active surveillance by use of periodical neurological assessment with incorporation of advanced neuroimaging techniques may be an option for selected patients given the non-negligible risk of morbidity and quality of life impairment following treatment of particularly incidental intracranial meningiomas [10-15]. In the context of cavernous sinus meningiomas, understanding of the natural history may play an integral role in decision making for management. However, limited data exist in the literature regarding the natural history of cavernous sinus meningiomas [16]. Growth of meningiomas within the cavernous sinus has been a less addressed issue, and series of radiation treatment typically focused on tumor growth under therapy without a control group of untreated cavernous sinüs meningiomas. In the comprehensive study by Amelot et al. focusing on this less addressed perspective, the evolution of cavernous sinus meningiomas were reported as unpredictable and irregular [16]. In contrast with meningiomas at other locations, modelling of growth rate profiles may be challenging for cavernous sinus meningiomas [16]. While some lesions may remain indolent for longer periods, gradual upsizing or abrupt manifestation with rapid progression may occur. It appears that thorough neuroimaging follow up is an indispensable component of conservative management of cavernous sinus meningiomas given the unpredictable natural history in a considerable proportion of lesions. Nevertheless, advances in neurosurgery may allow for an improved toxicity profile following surgical resection as the traditional and a leading mode of management for meningiomas located at accessible brain areas. Nevertheless, vigilance is required given the morbidity and mortality risks associated with meningioma surgery particularly for elderly patients [15,17-19]. Specific complications of surgery may include venous bleeding, intratumoral hemorrhages, damage to vital neurovascular structures such as the internal carotid artery, oculomotor nerve or the trigeminal nerve [16].

In this context, radiation therapy (RT) with conventional fractionation of radiosurgery delivered in a single or few treatment fractions may offer a viable alternative or adjunctive modality of management for meningiomas. Herein, we assess multimodality management of cavernous sinus meningiomas with less extensive surgery followed by subsequent irradiation.

\section{Irradiation as adjunct to incomplete surgery for caver- nous sinus meningiomas}

Combined modality management may be considered as a valuable strategy for selected patients with cavernous sinus meningiomas to avoid the potential risks of aggressive surgical resection and improve local control rates by incorporation of subsequent irradiation after limited surgery. Rationale of RT in this setting is to control progression of meningiomas after incomplete surgery. When the risk of radical resection as the principal mode of management is considered excessive, a tailored therapeutic approach may be utilized with 
incorporation of $\mathrm{RT}$ to achieve an improved toxicity profile with avoidance of the associated risks of aggressive surgery for selected patients harbouring lesions at eloquent brain regions such as the cavernous sinus [20-26].

Patients undergoing intended subtotal resection followed by radiosurgery as a deliberate valuable strategy were assessed in a comprehensive study [22]. Treatment approach consisted of single session radiosurgery with a mean margin dose of $\mathbf{1 4 . 5}$ Gray subsequent to limited surgery [22]. The authors concluded that surgery with subsequent radiosurgery provided safe and effective management of intracranial meningiomas located in close vicinity of critical structures [22].

Utility of conformal RT for cavernous sinus meningiomas was evaluated in another study in which patients were treated with conventionally fractionated radiation therapy (CFRT) as a definitive or complementary management modality [23]. Mean total RT dose was 52.9 Gray delivered over a period of 5 to 7 weeks with conventional fractionation using a median dose per fraction of 1.8 Gray [23]. The study reported satisfactory long term tumor control along with low treatment morbidity [23].

A technique utilizing combination of radiosurgery and microsurgery was reported as a viable bimodal approach to achieve improved cranial nerve functions in selected patients in a study for cavernous sinus meningiomas [24].

Management of 38 patients with sphenocavernous, clinoidocavernous, and sphenoclinoidocavernous meningiomas treated with surgery was assessed in a comprehensive study [25]. Twenty patients received irradiation after resection Reduction in tumor size or tumor control was achieved in 18 patients (90\%) out of the 20 patients receiving irradiation [25].

Long term follow-up outcomes of 31 patients undergoing RT with or without surgery for cavernous sinus meningiomas were reported by Dufour et al. [26]. Seventeen patients in the study were treated using a combined modality approach, and the results revealed a high rate of tumor control with a low risk of complications [26]. The authors concluded that RT could serve as a safe and effective treatment modality for initial or adjuvant management of cavernous sinus meningiomas considering the associated risks of complete aggressive surgical resection [26].

While the toxicity profile of RT may be more favorable than surgical resection for treatment of cavernous sinus meningiomas, adverse effects of irradiation also deserve consideration. Unlike surgical complications, toxicity of irradiation may also be observed as late effects in some patients. Deterioration in quality of life may occur due to untowards toxicity of irradiation such as edema, optic neuropathies, pituitary dysfunction. Ophthalmoplegia may also lead to emotional distress in some patients in addition to related visual disturbances. In this context, toxicity profile of a given treatment modality should be strongly considered in decision making for management of cavernous sinus meningiomas. Given the unpredictable behaviour in selected patients, a strict follow up strategy with periodical neuroimaging may be considered for active surveillance.

\section{Recent Advances in the discipline of radiation oncology}

There have been substantial improvements in irradiation techniques and technology in the millennium era. State of the art RT approaches have been introduced such as Intensity Modulated Radiation Therapy (IMRT), Adaptive Radiation Therapy (ART), and Image Guided Radiation Therapy (IGRT) [27-33]. Radiosurgical applications including Stereotactic Radiosurgery (SRS), Fractionated Stereotactic Radiation Therapy (FSRT), and Stereotactic Body Radiation Therapy (SBRT) have emerged as excellent therapeutic modalities for focused irradiation of many central nervous system disorders and a variety of distinct tumors located in the human body with stereotactic precise localization, excellent immobilization, and highly steep dose gradients around the target.allowing improved normal tissue sparing [34-66]. Radiosurgery is used to deliver extremely focused, high doses of radiation to relatively small, well defined targets under image guidance. There may be several radiobiological aspects of acquired results through the delivery of very high doses in a single fraction or a few fractions including induction of apoptosis and endothelial damage by ablative stereotactic irradiation [67-70].

\section{Conclusions and future perspectives}

Meningiomas are most common intracranial benign tumors. Although majority of meningiomas may follow an indolent disease course, affected patients may suffer from several symptoms due to the mass effect leading to compression of critical neurovascular structures. Management of cavernous sinus meningiomas in intricate association with critical neurovascular structures pose a formidable challenge to the treating physicians. Attempting at extensive surgical procedures may be associated with substantial morbidity and even mortality. In this context, selected patients may benefit from a tailored multimodality approach including less extensive surgical resection followed by subsequent irradiation. Primary advantages of this refined therapeutic strategy may include improved toxicity profile along with improved functionality and quality of life. Clearly, future studies may shed light on the role of this treatment approach in the management of cavernous sinus meningiomas.

\section{References}

1. Claus EB, Bondy ML, Schildkraut JM, Wiemels JL, Wrensch M, et al. (2005) Epidemiology of intracranial meningioma. Neurosurgery 57: 1088-1095. Link: https://bit.ly/30ilDRV

2. Bondy M, Ligon BL (1996) Epidemiology and etiology of intracranial meningiomas: A review. J Neurooncol 29: 197-205. Link: https://bit.ly/3hOGSyN

3. Shibuya M (2015) Pathology and molecular genetics of meningioma: recent advances. Neurol Med Chir 55: 14-27. Link: https://bit.ly/3fd5yCv

4. Buerki RA, Horbinski CM, Kruser T, Horowitz PM, James CD, et al. (2018) An overview of meningiomas. Future Oncol 14: 2161-2177. Link: https://bit.ly/2Y9kWZD 
5. Ostrom QT, Cioffi G, Gittleman H, Patil N, Waite K, et al. (2019) CBTRUS Statistical Report: Primary Brain and Other Central Nervous System Tumors Diagnosed in the United States in 2012-2016. Neuro Oncol 21: v1-v100. Link: https://bit.ly/378SsmV

6. Louis DN, Ohgaki H, Wiestler OD, Cavenee WK, Burger PC, et al. (2007) The 2007 WHO classification of tumours of the central nervous system. Acta Neuropathol 114: 97-109. Link: https://bit.ly/2XLzks9

7. Bhat AR, Wani MA, Kirmani AR, Ramzan AU (2014) Histological-subtypes and anatomical location correlated in meningeal brain tumors (meningiomas). $J$ Neurosci Rural Pract 5: 244-249. Link: https://bit.ly/2BBHsm6

8. Huang $\mathrm{RY}, \mathrm{Bi} \mathrm{WL}$, Griffith $\mathrm{B}$, Kaufmann $\mathrm{TJ}$, la Fougère $\mathrm{C}$, et al. (2019) International Consortium on Meningiomas., 2019. Imaging and diagnostic advances for intracranial meningiomas. Neuro Oncol 21: i44-i61. Link: https://bit.ly/2UjxnB1

9. Buetow MP, Buetow PC, Smirniotopoulos JG (1991) Typical, atypical, and misleading features in meningioma. Radiographics 11: 1087-1106. Link: Link: https://bit.ly/3cD47v7

10. Chamoun R, Krisht KM, Couldwell WT (2011) Incidental meningiomas. Neurosurg Focus 31: E19. Link: https://bit.ly/37ekQ7c

11. Spasic M, Pelargos PE, Barnette N, Bhatt NS, Lee SJ, et al. (2016) Incidental Meningiomas: Management in the Neuroimaging Era. Neurosurg Clin N Am 27: 229-238. Link: https://bit.ly/3h2nXU5

12. Islim Al, Mohan M, Moon RDC, Srikandarajah N, Mills SJ, et al. (2019) Incidental intracranial meningiomas: a systematic review and metaanalysis of prognostic factors and outcomes. J Neurooncol 142: 211-221. Link: https://bit.ly/2Yd5Sdf

13. Nakasu S, Nakasu Y (2020) Natural History of Meningiomas: Review with Meta-analyses. Neurol Med Chir (Tokyo) 60: 109-120. Link: https://bit.ly/3dICdiB

14. Nassiri F, Price B, Shehab A, Au K, Cusimano MD, et al. (2019) Life after surgical resection of a meningioma: a prospective cross-sectional study evaluating health-related quality of life. Neuro Oncol 21: i32-i43. Link: https://bit.ly/2UmoGFT

15. Islim Al, Mohan M, Moon RDC, Rathi N, Kolamunnage-Dona R, et al. (2020) Treatment outcomes of incidental intracranial meningiomas: Results from the IMPACT cohort. World Neurosurg Link: https://bit.ly/2MAuCqJ

16. Amelot A, van Effenterre R, Kalamarides M, Cornu P, Boch AL (2018) Natural history of cavernous sinus meningiomas. J Neurosurg 1-8. Link: https://bit.ly/2AN48Q8

17. Nunno A, Li Y, Pieters TA, Towner JE, Schmidt T, Shi M, et al. (2019) Risk Factors and Associated Complications of Symptomatic Venous Thromboembolism in Patients with Craniotomy for Meningioma. World Neurosurg 122: e1505-e1510. Link: https://bit.ly/2MFzsD6

18. Karhade AV, Fandino L, Gupta S, Cote DJ, Iorgulescu JB, et al. (2017) Impact of operative length on post-operative complications in meningioma surgery: a NSQIP analysis. J Neurooncol 131: 59-67. Link: https://bit.ly/2UltcEI

19. Steinberger J, Bronheim RS, Vempati P, Oermann EK, Ladner TR, et al. (2018) Morbidity and Mortality of Meningioma Resection Increases in Octogenarians. World Neurosurg 109: e16-e23. Link: https://bit.ly/2BDfnLe

20. Brastianos PK, Galanis E, Butowski N, Chan JW, Dunn IF, et al. (2019) Advances in multidisciplinary therapy for meningiomas. Neuro Oncol 21 i18-i31. Link: https://bit.ly/3cJqnDQ

21. Mathiesen T, Pettersson-Segerlind J, Kihlström L, Ulfarsson E (2014) Meningiomas engaging major venous sinuses. World Neurosurg 81: 116-124. Link: https://bit.ly/2Ulk8Qm

22. Aboukais R, Zairi F, Reyns N, Le Rhun E, Touzet G, et al. (2014)
Surgery followed by radiosurgery: a deliberate valuable strategy in the treatment of intracranial meningioma. Clin Neurol Neurosurg 124: 123 126. Link: https://bit.ly/3f0tSXR

23. Metellus P, Batra S, Karkar S, Kapoor S, Weiss S, et al. (2010) Fractionated conformal radiotherapy in the management of cavernous sinus meningiomas: long-term functional outcome and tumor control at a single institution. Int $\mathrm{J}$ Radiat Oncol Biol Phys 78: 836-843. Link: https://bit.ly/2A5mD2i

24. Couldwell WT, Kan P, Liu JK, Apfelbaum RI (2006) Decompression of cavernous sinus meningioma for preservation and improvement of cranial nerve function. Technical note. J Neurosurg 105: 148-152. Link: https://bit.ly/2BGFDV3

25. Abdel-Aziz KM, Froelich SC, Dagnew E, Jean W, Breneman JC, et al. (2004) Large sphenoid wing meningiomas involving the cavernous sinus: conservative surgical strategies for better functional outcomes. Neurosurgery 54: 1375-1383. Link: https://bit.ly/37eEfEP

26. Dufour H, Muracciole X, Métellus P, Régis J, Chinot O, et al. (2001) Longterm tumor control and functional outcome in patients with cavernous sinus meningiomas treated by radiotherapy with or without previous surgery: is there an alternative to aggressive tumor removal? Neurosurgery 48: 285 294. Link: https://bit.ly/3cFvd4L

27. Sager O, Dincoglan F, Demiral S, Uysal B, Gamsiz H, et al. (2019) Breathing adapted radiation therapy for leukemia relapse in the breast: $\mathrm{A}$ case report. World J Clin Oncol 10: 369-374. Link: https://bit.ly/2UnWHG1

28. Sager O, Dincoglan F, Uysal B, Demiral S, Gamsiz H, et al. (2018) Evaluation of adaptive radiotherapy (ART) by use of replanning the tumor bed boost with repeated computed tomography $(\mathrm{CT})$ simulation after whole breast irradiation (WBI) for breast cancer patients having clinically evident seroma. Jpn J Radio 36: 401-406. Link: https://bit.ly/2BGFQHP

29. Sager O, Dincoglan F, Uysal B, Demiral S, Gamsiz H, et al. (2017) Splenic Irradiation: A Concise Review of the Literature. J App Hem BI Tran 1: 101. Link: https://bit.ly/2UnGkJk

30. Sager O, Beyzadeoglu M, Dincoglan F, Demiral S, Uysal B, et al. (2015) Adaptive splenic radiotherapy for symptomatic splenomegaly management in myeloproliferative disorders. Tumori 101: 84-90. Link: https://bit.ly/30npxdh

31. Uysal B, Beyzadeoğlu M, Sager O, Dinçoğlan F, Demiral S, et al. (2013) Dosimetric evaluation of intensity modulated radiotherapy and 4-field 3-d conformal radiotherapy in prostate cancer treatment. Balkan Med J 30: 54 57. Link: https://bit.ly/2UjyKj9

32. Dincoglan F, Beyzadeoglu M, Sager O, Oysul K, Kahya YE, et al. (2013) Dosimetric evaluation of critical organs at risk in mastectomized left-sided breast cancer radiotherapy using breath-hold technique. Tumori 99: 76-82. Link: https://bit.ly/3f73FXX

33. Sager O, Beyzadeoglu M, Dincoglan F, Oysul K, Kahy YE, et al. (2012) Evaluation of active breathing control-moderate deep inspiration breath-hold in definitive non-small cell lung cancer radiotherapy. Neoplasma 59: 333-340. Link: https://bit.ly/2YfaHTB

34. Dincoglan F, Demiral S, Sage O, Beyzadeoglu M (2020) Utility of Multimodality Imaging Based Target Volume Definition for Radiosurgery of Trigeminal Neuralgia: An Original Article. Biomed J Sci Tech Res 26: 19728-19732. Link: https://bit.ly/2ASSd31

35. Sager O, Demiral S, Dincoglan F, Beyzadeoglu M (2020) Target Volume Definition for Stereotactic Radiosurgery (SRS) Of Cerebral Cavernous Malformations (CCMs). Canc Therapy Oncol Int J 15: 555-917. Link: https://bit.ly/2XF4Fws

36. Demiral S, Sager O, Dincoglan F, Uysal B, Gamsiz H, et al. (2018) Evaluation of Target Volume Determination for Single Session Stereotactic Radiosurgery (SRS) of Brain Metastases. Canc Therapy Oncol Int J 12: 555-848. Link: https://bit.ly/2AM50t1

Citation: Sager O, Beyzadeoglu M, Dincoglan F, Demiral S, Gamsiz H, et al. (2020) Multimodality management of cavernous sinus meningiomas with less extensive surgery followed by subsequent irradiation: Implications for an improved toxicity profile. J Surg Surgical Res 6(1): 056-061.

DOI: https://dx.doi.org/10.17352/2455-2968.000098 
37. Sager O, Dincoglan F, Demiral S, Gamsiz H, Uysal B, et al. (2019) Evaluation of the Impact of Magnetic Resonance Imaging (MRI) on Gross Tumor Volume (GTV) Definition for Radiation Treatment Planning (RTP) of Inoperable High Grade Gliomas (HGGs). Concepts Magnetic Resonance Part A 1-7. Link: https://bit.ly/3dJj403

38. Sager O, Dincoglan F, Demiral S, Gamsiz H, Uysal B, et al. (2019) Utility of Magnetic Resonance Imaging (Imaging) in Target Volume Definition for Radiosurgery of Acoustic Neuromas. Int J Cancer Clin Res 6: 119. Link: https://bit.ly/3cl2vQP

39. Demiral S, Sager O, Dincoglan F, Beyzadeoglu M (2019) Assessment of target definition based on Multimodality imaging for radiosurgical Management of glomus jugulare tumors (GJTs). Cancer Ther Oncol Int J 15: 555909. Link: https://bit.ly/30qra9y

40. Dincoglan F, Sager O, Demiral S, Beyzadeoglu M (2019) Multimodality Imaging for Radiosurgical Management of Arteriovenous Malformations. Asian Journal of Pharmacy, Nursing and Medical Sciences 7: 7-12. Link: https://bit.ly/37h0o30

41. Sager O, Dincoglan F, Demiral S, Beyzadeoglu M (2019) Evaluation of Radiosurgery Target Volume Determination for Meningiomas Based on Computed Tomography (CT) And Magnetic Resonance Imaging (MRI). Cancer Sci Res 5: 1-4. Link: https://bit.ly/3fd7J99

42. Beyzadeoglu M, Sager O, Dincoglan F, Demiral S (2019) Evaluation of Targe Definition for Stereotactic Reirradiation of Recurrent Glioblastoma. Arch Can Res 7: 3.

43. Demiral S, Sager O, Dincoglan F, Beyzadeoglu M (2019) Assessment of Computed Tomography (CT) And Magnetic Resonance Imaging (MRI) Based Radiosurgery Treatment Planning for Pituitary Adenomas. Canc Therapy Oncol Int J 13: 555-857. Link: https://bit.ly/3f74lwt

44. Dincoglan F, Sager O, Demiral S, Gamsiz H, Uysal B, et al. (2019) Fractionated stereotactic radiosurgery for locally recurrent brain metastases after failed stereotactic radiosurgery. Indian J Cancer 56: 151-156. Link: https://bit.ly/3dGI5sM

45. Dincoglan F, Sager O, Uysal B, Demiral S, Gamsiz H, et al. (2019) Evaluatıon of hypofractıonated stereotactıc radıotherapy (HFSRT) to the resectıon cavity after surgıcal resectıon of braın metastases: A sıngle center experıence. Indian J Cancer 56: 202-206. Link: https://bit.ly/37aOZ7a

46. Demiral S, Dincoglan F, Sager O, Uysal B, Gamsiz H, et al. (2018) Contemporary Management of Meningiomas with Radiosurgery. Int J Radiol Imaging Technol 4: 041. Link: https://bit.ly/3f24ukM

47. Dincoglan F, Sager O, Demiral S, Uysal B, Gamsiz H, et al. (2017) Radiosurgery for recurrent glioblastoma: a review article. Neurol Disord Therap 1: 1-5. Link: https://bit.ly/2BKG299

48. Demiral S, Dincoglan F, Sager O, Gamsiz H, Uysal B, et al. (2016) Hypofractionated stereotactic radiotherapy (HFSRT) for who grade I anterior clinoid meningiomas (ACM). Jpn J Radiol 34: 730-737. Link: https://bit.ly/3cGZcJU

49. Dincoglan F, Beyzadeoglu M, Sager O, Demiral S, Gamsiz H, et al. (2015) Management of patients with recurrent glioblastoma using hypofractionated stereotactic radiotherapy. Tumori 101: 179-184. Link: https://bit.ly/3eVLCUc

50. Sager O, Dincoglan F, Beyzadeoglu M (2015) Stereotactic radiosurgery of glomus jugulare tumors: current concepts. Recent advances and future perspectives. CNS Oncol 4: 105-114. Link: https://bit.ly/379bnOp

51. Gamsiz H, Beyzadeoglu M, Sager O, Demiral S, Dincoglan F, et al. (2015) Evaluation of stereotactic body radiation therapy in the management of adrenal metastases from non-small cell lung cancer. Tumori 101: 98-103. Link: https://bit.ly/2Un8tA

52. Demiral S, Beyzadeoglu M, Sager O, Dincoglan F, Gamsiz H, et al. (2014)
Evaluation of Linear Accelerator (Linac)-Based Stereotactic Radiosurgery (Srs) for the Treatment of Craniopharyngiomas. UHOD-Uluslararasi Hematoloji Onkoloji Dergisi 24: 123-129. Link: https://bit.ly/2AfV8D9

53. Dincoglan F, Sager O, Gamsiz H, Uysal B, Demiral S, et al. (2014) Management of patients with $\geq 4$ brain metastases using stereotactic radiosurgery boost after whole brain irradiation. Tumori 100: 302-306. Link: https://bit.ly/379brO9

54. Gamsiz H, Beyzadeoglu M, Sager O, Dincoglan F, Demiral S, et al. (2014) Management of pulmonary oligometastases by stereotactic body radiotherapy. Tumori 100: 179-183. Link: https://bit.ly/3cFwvg7

55. Sager O, Beyzadeoglu M, Dincoglan F, Gamsiz H, Demiral S, et al. (2014) Evaluation of linear accelerator-based stereotactic radiosurgery in the management of glomus jugulare tumors. Tumori 100: 184-188.

56. Sager O, Beyzadeoglu M, Dincoglan F, Uysal B, Gamsiz H, et al. (2014) Evaluation of linear accelerator (LINAC)-based stereotactic radiosurgery (SRS) for cerebral cavernous malformations: a 15-year single-center experience. Ann Saudi Med 34: 54-58

57. Dincoglan F, Beyzadeoglu M, Sager O, Uysal B, Demiral S, et al. (2013) Evaluation of linear accelerator-based stereotactic radiosurgery in the management of meningiomas: a single center experience. J Buon 18: 717722. Link: https://bit.ly/3cFwwAH

58. Sager O, Dincoglan F, Demiral S, Uysal B, Gamsiz H, et al. (2018) A concise review of immunotherapy for glioblastoma. Neuroimmunol Neuroinflammation 5: 25. Link: https://bit.ly/37bNGoC

59. Demiral S, Dincoglan F, Sager O, Gamsiz H, Uysal B, et al. (2016) Hypofractionated stereotactic radiotherapy (HFSRT) for who grade anterior clinoid meningiomas (ACM). Jpn J Radiol 34: 730-737. Link: https://bit.ly/3f74XSN

60. Demiral S, Beyzadeoglu M, Uysal B, Oysul K, Kahya YE, et al. (2013) Evaluation of stereotactic body radiotherapy (SBRT) boost in the management of endometrial cancer. Neoplasma 60: 322-327. Link: https://bit.ly/2A4oXXn

61. Sager O, Beyzadeoglu M, Dincoglan F, Demiral S, Uysal B, et al. (2013) Management of vestibular schwannomas with linear accelerator-based stereotactic radiosurgery: A single center experience. Tumori 99: 617-622. Link: https://bit.ly/3gXU8UC

62. Dincoglan F, Sager O, Gamsiz H, Uysal B, Demiral S, et al. (2012) Stereotactic radiosurgery for intracranial tumors: A single center experience. Gulhane Med J 54: 190-198. Link: https://bit.ly/37lx7Xz

63. Dincoglan F, Sager O, Gamsiz H, Demiral S, Uysal B, et al. (2012) Management of arteriovenous malformations by stereotactic radiosurgery: A single center experience. UHOD-Uluslararasi Hematoloji Onkoloji Dergisi 22: 107-112. Link: https://bit.ly/37chYrl

64. Surenkok S, Sager O, Dincoglan F, Gamsiz H, Demira S, et al. (2012) Stereotactic radiosurgery in pituitary adenomas: A single center experience. UHOD-Uluslararasi Hematoloji Onkoloji Dergisi 22: 255-260. Link: https://bit.ly/2BKw0EX

65. Dincoglan F, Beyzadeoglu M, Sager O, Oysul K, Sirin S, et al. (2012) Image guided positioning in intracranial non-invasive stereotactic radiosurgery for the treatment of brain metastasis. Tumori 98: 630-635. Link: https://bit.ly/3f2sXX6

66. Sirin S, Oysul K, Surenkok S, Sager O, Dincoglan F, et al. (2011) Linea accelerator-based stereotactic radiosurgery in recurrent glioblastoma: A single center experience. Vojnosanit Pregl 68: 961-966. Link: https://bit.ly/3cMapZn

67. Kim MS, Kim W, Park IH, Kim HJ, Lee E, et al. (2015) Radiobiological mechanisms of stereotactic body radiation therapy and stereotactic radiation surgery. Radiat Oncol J 33: 265-275. Link: https://bit.ly/3h4bL58

68. Karam SD, Bhatia S (2015) The radiobiological targets of SBRT: tu-

Citation: Sager O, Beyzadeoglu M, Dincoglan F, Demiral S, Gamsiz H, et al. (2020) Multimodality management of cavernous sinus meningiomas with less extensive surgery followed by subsequent irradiation: Implications for an improved toxicity profile. J Surg Surgical Res 6(1): 056-061.

DOI: https://dx.doi.org/10.17352/2455-2968.000098 
mor cells or endothelial cells?. Ann Transl Med 3: $290 . \quad$ Link: https://bit.ly/3gYS8M1

69. Song CW, Kim MS, Cho LC, Dusenbery K, Sperduto PW (2014) Radiobiological basis of SBRT and SRS. Int J Clin Oncol 19: 570-578. Link: https://bit.ly/2BMMT1X
70. Brown JM, Carlson DJ, Brenner DJ (2014) The tumor radiobiology of SRS and SBRT: are more than the 5 Rs involved? Int J Radiat Oncol Biol Phys 88: 254 262. Link: https://bit.ly/30kLeul

\section{Discover a bigger Impact and Visibility of your article publication with} Peertechz Publications

\section{Highlights}

- Signatory publisher of ORCID

* Signatory Publisher of DORA (San Francisco Declaration on Research Assessment)

* Articles archived in worlds' renowned service providers such as Portico, CNKI, AGRIS, TDNet, Base (Bielefeld University Library), CrossRef, Scilit, J-Gate etc.

- Journals indexed in ICMJE, SHERPA/ROMEO, Google Scholar etc.

- OAI-PMH (Open Archives Initiative Protocol for Metadata Harvesting)

* Dedicated Editorial Board for every journal

* Accurate and rapid peer-review process

* Increased citations of published articles through promotions

* Reduced timeline for article publication

Submit your articles and experience a new surge in publication services (https://www.peertechz.com/submission).

Peertechz journals wishes everlasting success in your every endeavours.

Copyright: (c) 2020 Sager 0, et al. This is an open-access article distributed under the terms of the Creative Commons Attribution License, which permits unrestricted use, distribution, and reproduction in any medium, provided the original author and source are credited.

Citation: Sager O, Beyzadeoglu M, Dincoglan F, Demiral S, Gamsiz H, et al. (2020) Multimodality management of cavernous sinus meningiomas with less extensive surgery followed by subsequent irradiation: Implications for an improved toxicity profile. J Surg Surgical Res 6(1): 056-061.

DOI: https://dx.doi.org/10.17352/2455-2968.000098 